DOI: $10.15393 /$ j10.art.2019.4121

УДК $821.161 .1+930.253$

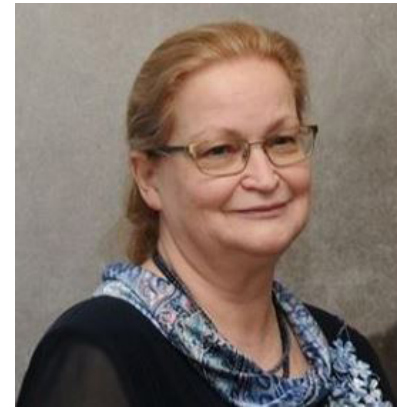

Е. М. Варенцова

Государственный музей истории российской литературы имени В. И. Даля (Москва, Российская Федераиия)

orfglm@gmail.com

\title{
Достоевские в Даровом \\ (по материалам рукописного отдела Государственного музея истории российской дитературы им. В. И. Даля)*
}

Аннотация. Документальных свидетельств о детстве и отрочестве Федора Михайловича Достоевского крайне мало. Но, кроме «прямых» свидетельств, существуют и так называемые «косвенные», в которых страницы биографии Достоевского или события, связанные с жизнью семьи писателя, зафиксированы опосредованно. Таковыми источниками в первую очередь являются разного рода официальные бумаги, относящиеся к имущественнохозяйственной сфере. В составе рукописного фонда Государственного музея истории российской литературы им. В. И. Даля хранятся обыскные книги церкви Сошествия Святого Духа на апостолов в селе Моногарове, анализ которых в данной статье позволил внести новые детали к биографии семьи Достоевских, дополнить несколькими неизвестными датами «Летопись жизни и творчества Ф. М. Достоевского». В статье дается археографическое описание этих документов. Особое внимание уделено автографам Марии Федоровны, Михаила Андреевича и Михаила Михайловича Достоевских 1830-х - 1850$\mathrm{x}$ гг.

Ключевые слова: детство Достоевского, М. Ф. Достоевская, М. А. Достоевский, М. М. Достоевский, В. М. Иванова, обыскные книги, Даровое, Моногарово

Об авторе: Варенияова Евгения Михайловна - заведующая отделом рукописных фондов, Государственный музей истории российской литературы имени В. И. Даля (Государственный литературный музей) (ул. Достоевского, 2, г. Москва, Российская Федерация, 103030) Дата поступления: 25.07.2019

Дата публикации: 14.09.2019

Для цитирования: Варенцова Е. М. Достоевские в Даровом (по материалам рукописного отдела Государственного музея истории российской литературы им. В. И. Даля) // Неизвестный Достоевский. — 2019. - № 3. - C. 5-17. DOI: 10.15393/j10.art.2019.4121

$7 \begin{aligned} & \text { окументальных свидетельств о детстве и отрочестве Федора Михайловича } \\ & \text { Достоевского известно немного: это книга записей о крещении и от- }\end{aligned}$ певании в храме святых апостолов Петра и Павла при Мариинской больнице

(C) Е. М. Варенцова, 2019 
для бедных, переписка Михаила Андреевича и Марии Федоровны Достоевских, несколько писем Ф. М. Достоевского к родителям. Основным источником наших знаний о детстве писателя являются воспоминания его младшего брата Андрея, а также рассыпанные по страницам художественных произведений и эпистолярия Достоевского фрагменты воспоминаний. Однако, кроме «прямых» свидетельств, существуют и так называемые «косвенные», в которых страницы биографии Достоевского или события, связанные с жизнью семьи писателя, зафиксированы опосредованно. Таковыми источниками в первую очередь являются разного рода официальные бумаги, относящиеся к имущественно-хозяйственной сфере.

В составе рукописного фонда Государственного музея истории российской литературы им. В. И. Даля (второе название Государственного литературного музея - ГЛМ) хранятся обыскные книги церкви Сошествия Святого Духа на апостолов села Моногарова. Их анализ позволит дополнить биографию семьи Достоевских новыми событиями и датами.

Перед тем как перейти к обзору обыскных книг, приведем отрывок из воспоминаний В. С. Нечаевой об истории основания первого музея Ф. М. Достоевского: «...я предполагала использовать время для лучшего знакомства с Даровым, Черемошней и окружающей местностью. Прежде всего я направилась в соседнее Моногарово, бывшее имение Хотяинцевых, в котором хорошо сохранилась церковь конца XVIII в. Ее посещали Достоевские и их крестьяне, около нее был похоронен М. А. Достоевский. Церковь стояла открытая, пустая и явно никем не охранялась. Я обратила внимание на старинные бумаги, разбросанные при входе, пошла по их следам и увидела в полутемной сырой комнате церковный архив, из которого без разбора вырывали бумагу. Как архивист, я “прилипла" к этим полкам и здесь провела весь день, забыв обо всем остальном. Я очень скоро поняла огромное значение, которое могут иметь хранившиеся здесь “клировые ведомости", книги “брачных обысков” и другие документы» [Нечаева, 1985: 293]. Ради спасения церковных документов В. С. Нечаева отправилась в сельсовет, где получила разрешение на вывоз материалов в фонд Музея Ф. М. Достоевского в Москве, и ее даже «снабдили хорошим мешком, в который можно было уложить десяток толстых томов церковных ведомостей за интересовавшие» ее годы пребывания Достоевских в Даровом.

К сожалению, из этого «хорошего мешка» в рукописный отдел ГЛМ попали лишь три обыскных книги и одна ведомость за 1835 г. с записями о людях, прошедших исповедь и причастие. Данные о дворовых и крестьянах, принадлежавших Достоевским, из этой книги-ведомости В. С. Нечаева опубликовала в книге «В семье и усадьбе Достоевских» в 1939 г. [Нечаева, 1939: 128131]. Вернувшись из командировки, Вера Степановна сразу же поместила обыскные книги и ведомость в экспозицию недавно созданного ею (в 1928 г.) Музея Ф. М. Достоевского, тогда самостоятельного учреждения. Документы 
получили инвентарные номера музея (№№ 44, 57-59), и это спасло их от перемещения в другие архивохранилища.

Первая по времени обыскная книга относится к 1807-1832 гг. ${ }^{1}$ Она в темном мягком переплете с холщовым корешком, прошнурована и имеет большую сургучную печать, заверяющую запись о том, что всего «в сей книге номерованных сто тридцать шесть листов». Это листы голубой бумаги русского производства 1805 г. с филигранью “Pro Patria” со львом.

На первой странице книги имеется длинное заглавие: «Книга, данная изъ Тульской Духовной Консисторіи, Каширской округи села Моногарова иеркви Сошествія Святаго Духа свяшенно и иерковнослужителямь, для вписьванія импющимг вступить въ браци приходскихъ людей объсковъ по данной форми».

Обыск брачный - это «свидетельство о неродстве, и записка об этом в церковной книге»². Согласно статье в словаре Брокгауза и Ефрона, «обыск церковный - письменный акт, составляемый причтом церкви пред венчанием каждого брака и удостоверяющий наличность условий, требуемых законом для совершения брака. <...> Этот акт, установленный в 1765 году (нынешняя его форма составлена в 1837) подписывается женихом и невестою, двумя или тремя поручителями (и причтом церкви с 1837)»³.

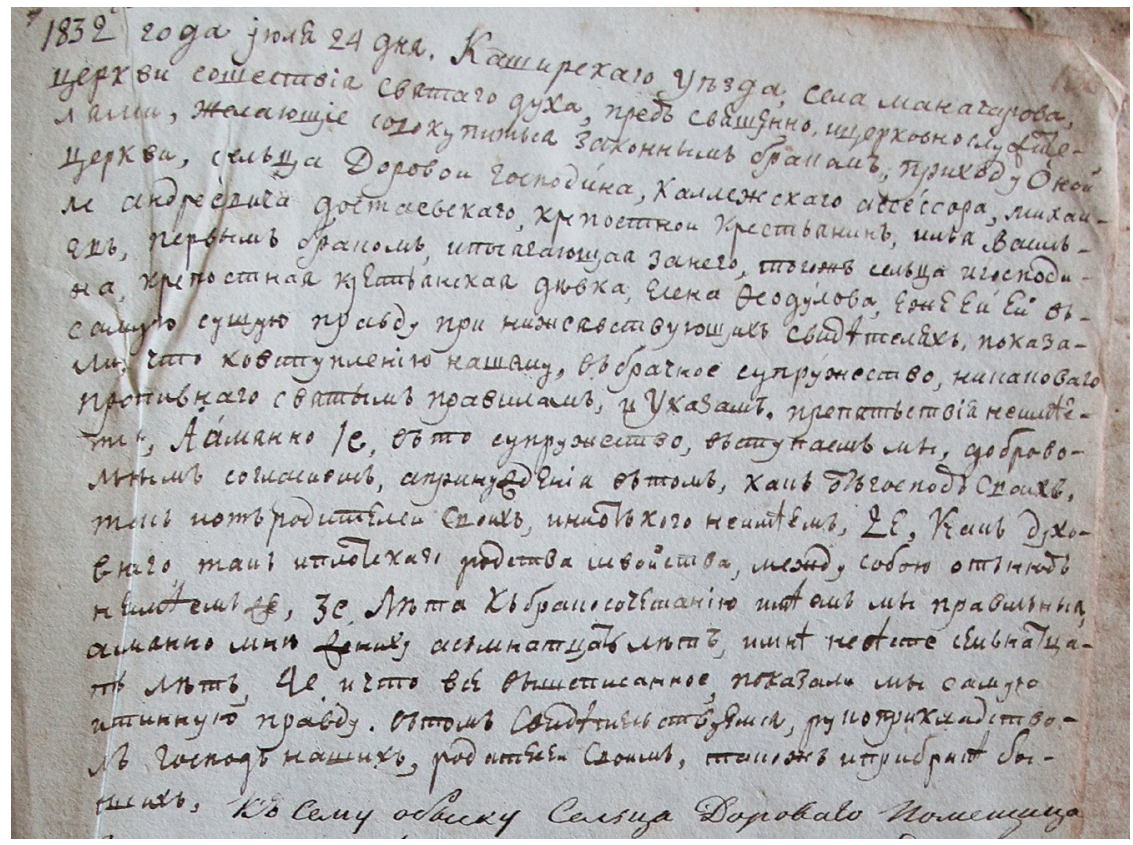

Илл. 1. Фрагмент рукописи. Ф. 81. Оп. 1. Ед. хр. 128. Л. 130.

В этой первой по времени обыскной книге нам интересна всего одна запись. Она находится на последнем, 136 листе, под № 5 за 1832 г. Это первое упоминание членов семьи Достоевских в качестве владельцев сельца Даровое. 
В предыдущей записи, сделанной почти годом ранее, 17 мая 1831 г. (л. 130 об.), деревня Даровая принадлежала господину Павлу Петровичу Хотяинцеву. 24 июля 1832 г. деревня Даровая обозначена как сельцо, уже с другим хозяином. Для того чтобы иметь представление о записях в «Обыскных книгах», приведем первую запись полностью (см. илл. 1):

«1832го года іюля 24 дня. Каширскаго упзда, села Манагарова, иеркви Сошествіа Святаго духа, предъ священно и церковнослужителами, желающіе совокупиться законнымъ бракомъ, приходу Оной церкви, сельца Доровои Господина, Каллежскаго ассессора, Михаила Андреевича Достаевскаго, крепостнои крестьянинг, Ильа Васильевъ, первымъ бракомг, и посягающая за него, тогожь сельиа и господина, крепостная крестьанская дювка, Елена Өеодулова. Еже ей ей въ самую сущую правду при ниже явствующихъ свидютеляхъ, показали, что ко вступленію начему, въ брачное супружество, никаковаго противнаго святымб правиламб, и Указамь препятьствія не импется. А имянно le, въ то супружество, въступаемъ мы, добровольнымб согласиемб, а принужденіа въ томъ, какъ отъ господъ своихъ, такъ и отъ родителей своихъ, и ни отъ кого не импемъ, 2е, Какъ духовнаго, такъ и плотскаго родства и свойства, между собою отбнюдь не импемъ же, Зе, Люта къ бракосочетанію импемь мы правильныя, а <и>мянно мнпь жениху асьмнатиать лпьть, и мнгь невпьсте семьнатиать лпть, 4е, и что все вышеписанное, показали мы самую истинную правду. Въ томг свидютельствуемся, рукоприкладствомг Господъ нашихъ, родителей своимъ, такожъ и при бракп бывщихъ».

Ниже следуют записи поручителей. Первая написана четким красивым почерком и занимает всего три строки: «Къ Сему обыску Сельца Дороваго Помещища Коллежская Ассессорша Марія Федорова дочь Достоевская руку приложила» ${ }^{4}$. Это первый из двух имеющихся в обыскных книгах автограф Марии Федоровны.

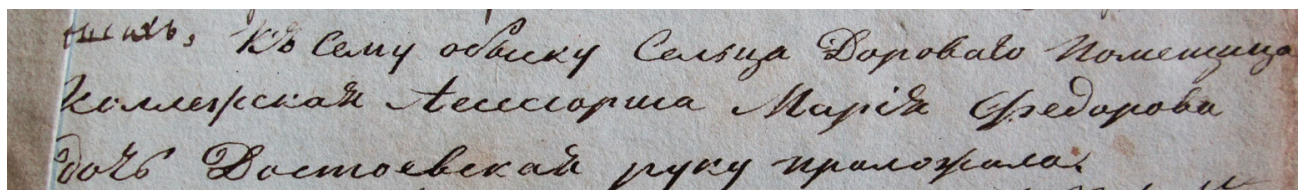

Илл. 2. Автограф М. Ф. Достоевской. Ф. 81. Оп. 1. Ед. хр. 128. Л. 130.

Запись второго поручителя расположена ниже и занимает 16 строк, сделана с многочисленными ошибками, слева от нее - чернильное пятно от печати на обороте листа: «Ксиму обыска въ места жиниха и невесты и по женихе поручителей той же вотчины и тойже госпожи крппоостныхъ ея крестьянб, Савина Макарова Илие Лаврентьева Никиты Иванова по невтоте села Моногарова Господина Павла Петровича Хотяинцова крестьянинб Феодора Иванова и той же госпожи Дастаевской крестьянъ Петра Савинова и Феодота Иванова и по ихъ тичному проченію той же Госпожи дворовой 


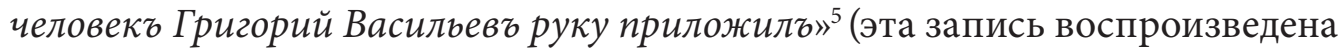
в книге В. С. Нечаевой «В семье и усадьбе Достоевских» в виде иллюстрации на вклейке после 112 страницы. - См. илл. 3).

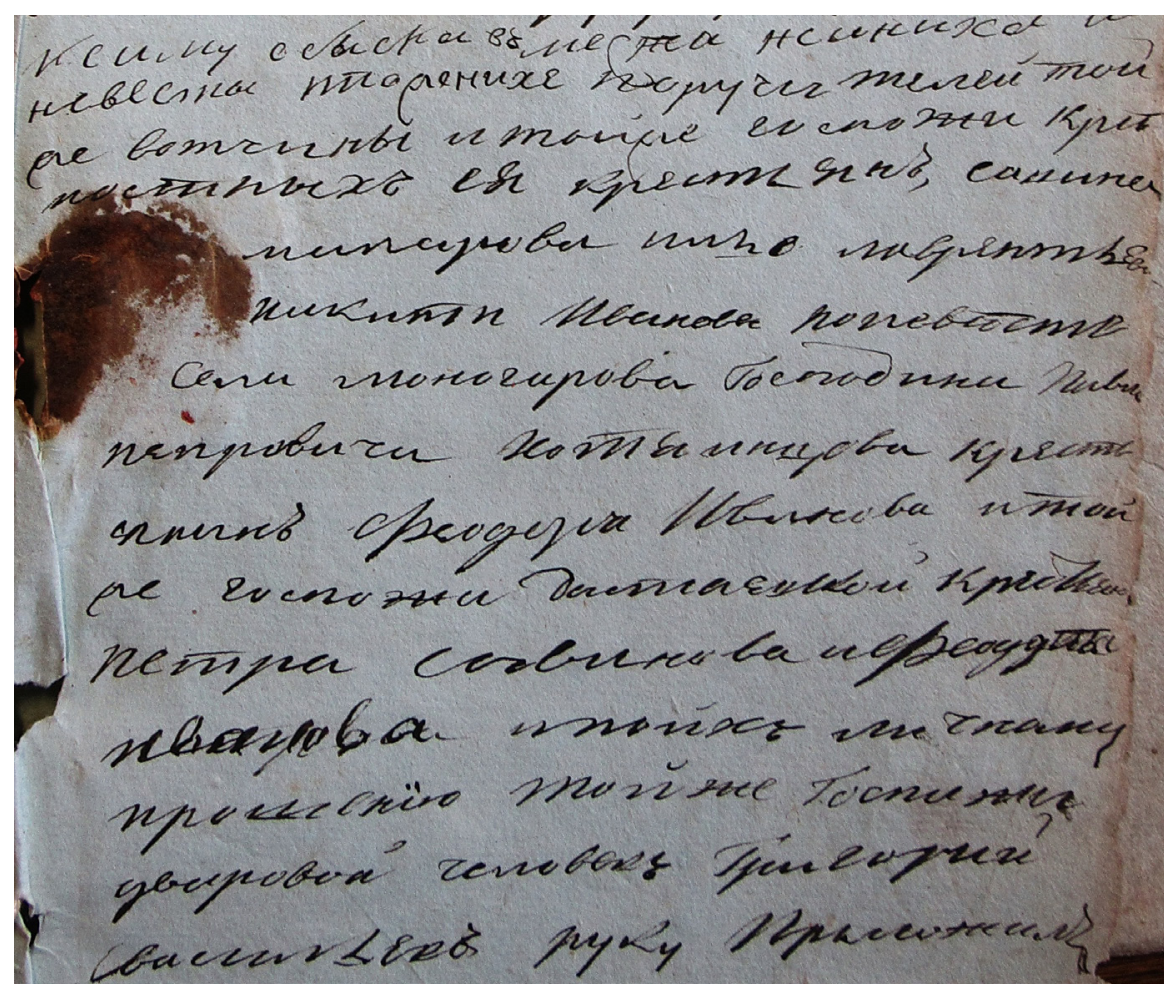

Илл. 3. Автограф Григория Васильева. Ф. 81. Оп. 1. Ед. хр. 128. Л. 130.

Григорий Васильев подписывается как дворовый человек Марии Федоровны Достоевской, таковым же он числится и по церковной ведомости 1835 г. Он не принадлежал к коренным жителям Дарового и был привезен из Москвы. В обиходе же он исполнял должность приказчика семьи Достоевских [Нечаева, 1939: 155] и имел полное доверие от своих хозяев. Он представлен на страницах романа «Братья Карамазовы» в образе слуги Федора Павловича Карамазова, которому автор дал то же имя - Григорий Васильев. Упоминается он как персонаж и в «Дневнике писателя» за 1876 г. в рассказе о пожаре деревни:

«Вдруг отворилась дверь, и на пороге показался наш дворовый человек, Григорий Васильев, сейчас только из деревни прибывший. В отсутствие господ ему даже поручалось управление деревней, и вот вдруг вместо “управляющего”, всегда одетого в немецкий сюртук и имевшего солидный вид, явился человек в старом зипунишке и в лаптях. Из деревни пришел пешком, а войдя, стал в комнате, не говоря ни слова. 
- Что это? - крикнул отец в испуге. - Посмотрите, что это?

- Вотчина сгорела-с! - пробасил Григорий Васильев» [Достоевский: 112$]^{6}$.

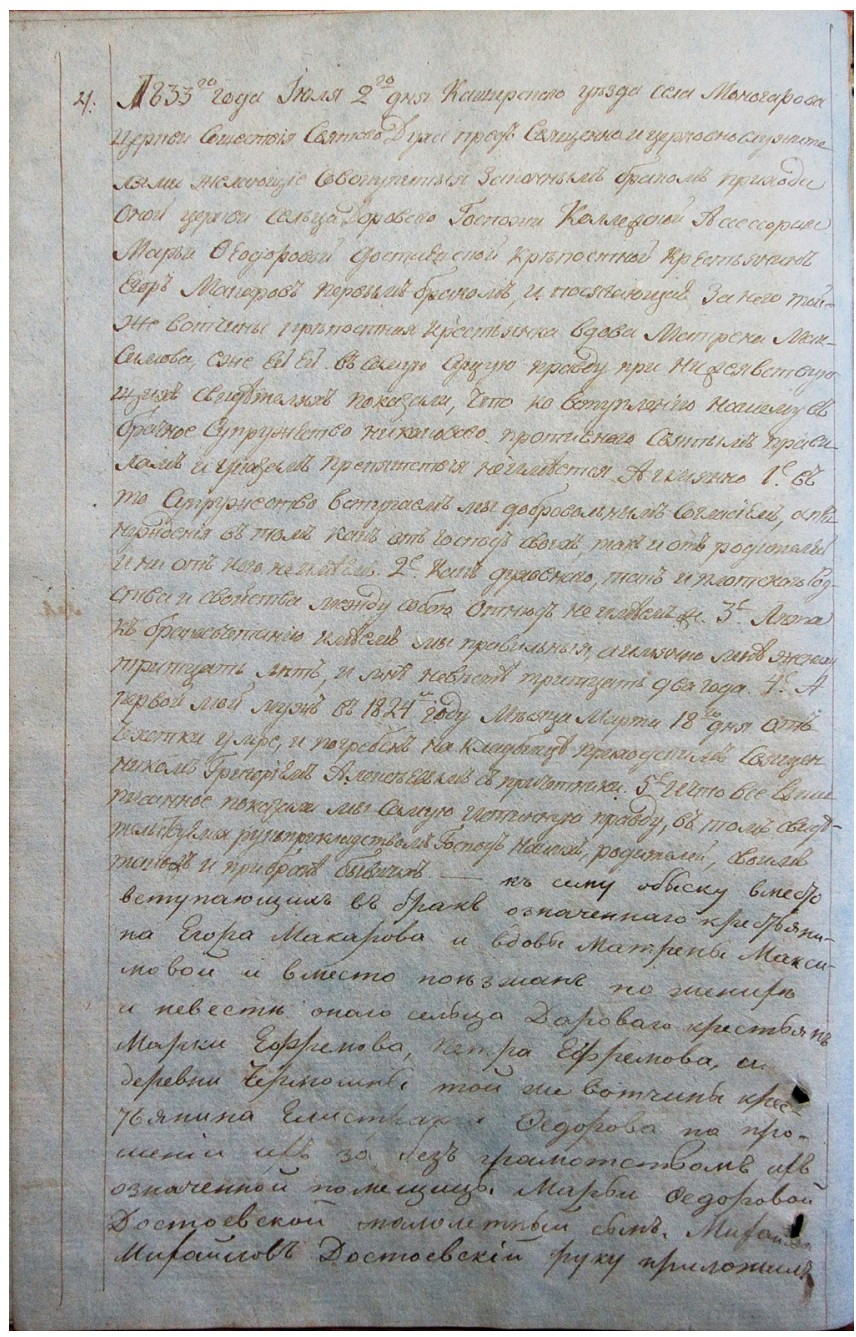

Илл. 4. Ф. 81. Оп. 1. Ед. хр. 130. Л. 4 об.

Вторая обыскная книга в собрании ГЛМ датируется с 26 сентября 1832 г. (продолжение предыдущей) по 11 ноября 1838 г. включительно7. Она утратила переплет и шнуровку. Заверительная запись о количестве листов отсутствует. Всего в книге 34 листа голубого цвета бумаги Московской округи Копинской фабрики Елизаветы Баташевой.

На обороте листа 4 в книге имеется запись под № 4 от 2 июля 1833 г.: «... желающіе совокупиться законнымъ бракомъ прихода оной церкви сельца 
Дороваго Госпожи Коллежской Ассессорши Марьи Өеодоровой Достаевской крппостной крестьянинъ Егоръ Макаровъ первымъ бракомъ, и посягающяая за него тойже вотчины крппостная крестьянка вдова Матрена Максимова...». Далее следует типовой текст о добровольном вступлении в брак, об отсутствии родства между молодоженами, об их возрасте и об истинности их показаний.

Затем идет запись поручителя: «Къ сему обыску вместо вступающихъ въ бракъ означеннаго крестьянина Егора Макарова и вдовы Матрены Максимовой и вместо попзжанъ по женихп и невестп онаго сельиа Дароваго крестьянъ Марка Ефремова, Петра Ефремова, и деревни Чермошны той же вотчины крестьянина Елистрата Өедорова по проченіи ихъ за безб грамотствомъ ихъ означенной помещицы Марьи Өедоровой Достоевской малолетный сынъ Михаиль Михайловъ Достоевскій руку приложилъ» $(\text { выделено мной. - E. B.) })^{8}$. Это первый автограф почти 13-летнего Михаила Михайловича на страницах обыскных книг и первое упоминание деревни Чермошни (см. илл. 4).

«Малолетний сын» М. М. Достоевский засвидетельствовал, но уже вместе с матерью обыскную запись от «1834 года мая 21 дня» за № 2: «сельияа Чермошной Господина Надворнаго Совптника и Кавалера Михаила Андрпевича, сына Достоевскаго» крепостного крестьянина Федора Федорова с девицей Анисьей Автамоновой «изъ села Касяева Госпожи дювицы Екатерины Ларионовой, дочери Философова» в старой орфографии. Сначала стоит подпись «Надворная Советница Марія Федорова дочь Достоевская». Это второй и, к сожалению, последний автограф матери Ф. М. Достоевского. Далее с новой строки расположился автограф ее сына: «Къ сему обыску вмпсто поручителей по женихп сельца Черемошны оной же вотчины крестьянь Алекспя Феодорова, Михаила Леонтіева, сельца Дароваго крестьянина Семена Иванова, по невтьстп сельиа Черемошнь крестьянь Митробана Григорьева, Егора Сергпева, деревни Любиловки Господина Груздева крестьянина Ивана Петрова по незнанію грамоть Господина Надворнаго Совютника Михаила Андрпевича Достоевскаго малолптный сынъ Михаиль Михайловъ Достоевской nодписался»" . В отличие от первой приведенной записи «малолетний сын» теперь представляется как сын отца - Михаила Андреевича, а не матери, как в прошлом году (2 июля 1833 г.). Вместо традиционного «руку приложил» впервые стоит светское «подписался».

Следует обратить особое внимание на эти автографы Марии Федоровны и ее малолетнего сына Михаила Михайловича. Зная сложившиеся в семье отношения и принимая в расчет обычаи жизни барской усадьбы, можно с полной уверенностью утверждать, что свидетелем этих свадебных церемоний был и малолетний Федор Михайлович Достоевский. В это время ему 11-13 лет. Это возраст активного восприятия мира, знакомства с правилами и обычаями социальной жизни. Среди летних впечатлений мальчика Достоевского не только игры с братьями и крестьянскими детьми в «дикарей», не только чтение исторических романов Вальтера Скотта, наблюдения за трудовой 
жизнью сельских жителей, регулярные походы с матушкой в церковь, но и, как видим из записей в обыскных книгах, свадебные торжества и обряды волнующая тайна взросления и освоения новых социальных ролей.

Даты 24 июля 1832 г., 2 июля 1833 г. и 21 мая 1834 г., не включенные в «Летопись жизни и творчества Ф. М. Достоевского», должны быть учтены в дальнейших исследованиях биографии писателя и его родственников.

Во второй обыскной книге есть записи о крестьянах, принадлежавших семье Достоевских, но уже без личных подписей господ: одна 1833 г. - от 29 октября (л. 9); пять от 1836 г. - от 19 (две) и 23 января (л. 18 об. - 19 об.), от 2 октября (л. 22) и 8 ноября (л. 23); три записи 1838 г. - от 4 февраля (л. 24 об.), 23 мая (л. 26) и 6 ноября (л. 32).

Из них наиболее интересными представляются записи от 19 января 1836 г. Вступающие в брак крестьяне (и жених, и невеста) из сельца Чермошны и сельца Дарового принадлежат, согласно тексту, «господину надворному совптнику и кавалеру Михаилу Андрпевичу сыну Достоевскому». Поручителями за них были «по женихп тогожь сельиа Доровой и господина Достаевскаго крепостные крестьяне Илья Лаврентьевъ и сельияа Чермошной крестьяне Егорь Серьгпевъ и Василей Никитинъ; по нгвпсте, сельиа же Доровой господина маіора Павла Петровича Хотяинцова крестьяне Петръ Васильевъ и Денисъ Макаровъ» (л. 18 об.). Указаны два владельца. Согласно соседней записи (л. 19) от того же числа, «молодые» из Дарового и Чермошны принадлежат тому же Михаилу Андреевичу Достоевскому. Однако заверительная запись свидетельствует: «...сельца Доровой Господина надворнаго совптника Михаила Андргевича Достаевскаго крестьяне Симпонъ Ивановъ и Никита Ивановъ. По нпвпсте, сельиа Чермошны тогожв господина Достаевскаго крестьянинъ Ефимь Максимовъ, и сельиа Доровой Господина Хотяйниьова крестьянинъ Никифорь Васильевъ». В этой записи снова указаны два владельца крестьян, проживающих в Даровом: прежний (П. П. Хотяинцев) и нынешний (М. А. Достоевский). Следовательно, по каким-то причинам часть своих крепостных П. П. Хотяинцев не продал, а оставил за собой. Дворы этих крестьян находились на территории имения Достоевских. Эта чересполосица была очень неудобна, и Достоевские подали иск в Каширский суд о выселении дворов Хотяинцева с их земли. Так началась долгая тяжба между соседями. Однако это не мешало им оказывать взаимные дружеские услуги. Например, двое грамотных дворовых людей из села Дарового и села Моногарова, принадлежавших Хотяинцеву, Никифор Васильев и Алексей Сергеев, наряду с вышеупомянутым дворовым Достоевских Григорием Васильевым, подписывали («за неумением грамоты» у крестьян) обыскные записи в отсутствие членов семьи Достоевских.

Третья обыскная книга церкви Сошествия Св. Духа села Моногарова, хранящаяся в ГЛМ, датируется 1838-1855 гг. ${ }^{11}$ Она в твердом картонном переплете, оклеенном коричневой «мраморной» бумагой. Корешок утрачен. На верхней крышке переплета бумажная красная наклейка с узором по краям, на которой написано: «Книга обыскная с 1838 года». В связи с реформами 
императора Николая I, вводится обыскная книга нового образца ${ }^{12}$. Появляется в начале книги печатная статья «Форма обыска брачнаго», где вместо имевшихся прежде четырех пунктов теперь требуется заполнять десять, да еще и с подпунктами. Отпечатаны и «Примечания», где указываются необходимые документы (в том числе аттестат о службе жениха, официальное извещение «о летах» и другие). Ранее этого не требовалось. Язык документа утратил церковно-славянскую традицию, стал современным. Изменилась и форма записей на казенно-бюрократическую.

Эта перемена стиля документов чувствуется в первой же записи на л. 1 третьей обыскной книги: «1839го года Апрпля 2 Дня по указу Его императорскаго величества, Качирскаго упзда села Манагарова Святодуховской церкви священно-церковно служители производили обыскб о желающихь въступить въ бракъ, и оказалось слюдующее. 1) женихъ сельца Дорова́го (с ударением на а. - E. В.) Господина Коллежскаго совптника Михаила Андргевича Достаевскаго крппостной крестьянской сынъ Петръ Сидоровъ, чухнинб, православнаго впроисповпданія, жительствуеть означеннаго сельиза Доровой въ приходю сей иеркви. 2) невпьта сельи, Чермошной, тогожъ господина Достаевскаго крппостная крестьянская дочь Марина Ефимова, православнаго въроисповпданія...». И так далее. Появились и новые требования, в том числе обязательным стало письменное разрешение владельца крепостных на их брак. Заканчивается запись, ставшая вдвое длиннее, предостережением подписавшимся поручителям об ответственности за ложные показания перед судом церковным и гражданским. После этого следует подпись владельца будущих молодоженов. В данном случае очень лаконичная, но для нас очень важная: «Къ сему обыску Коллежской Совптникъ и Кавалеръ Михаиль Достоевскій руку приложиль».

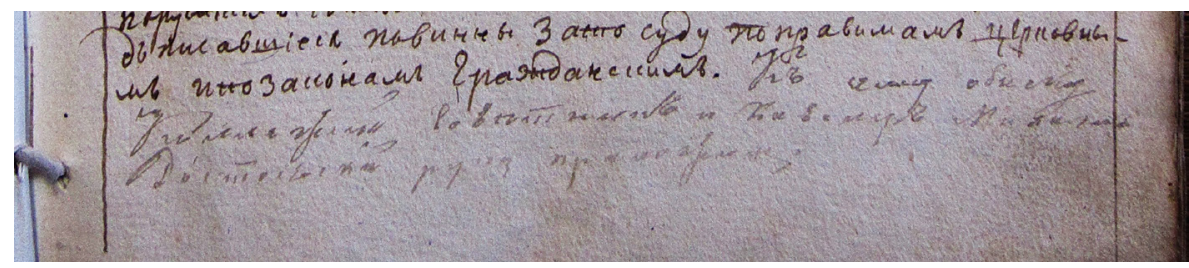

Илл. 5. Ф. 81. Оп. 1. Ед. хр. 131. Л. 1.

Вероятно, Михаил Андреевич в это время (2 апреля 1839 г.) жил в Даровом или специально приехал в связи с грозными новыми правилами о необходимости письменного разрешения на брак принадлежавших ему крестьян, но это единственный его автограф в обыскных книгах ${ }^{13}$. Далее в брачной записи поименованы крестьяне-свидетели, за которых «руку приложил» уже известный нам «Г-на Маіора Павла Петровича Хотяинцова служитель Алюксей Сергпевъ». В самом конце стоят подписи священника, дьякона, дьячка и пономаря (что требовалось по новым правилам). 
Следующая обыскная запись о крепостных Михаила Андреевича Достоевского появилась 6 ноября 1839 г. $^{14}$, т. е. после его смерти. Засвидетельствовал ее «покойнаго господина Достоевскаго чилавекъ Григорій Васильевъ».

Согласно брачным записям от 13 апреля, 1 и 8 октября 1841 г. крепостные крестьяне сельца Чермошны и сельца Дарового принадлежат все тому же покойному господину коллежскому советнику и кавалеру Михаилу Андреевичу Достоевскому ${ }^{15}$.

Изменения появляются 2 ноября $1841 \mathrm{r}^{16}$ Впервые упоминается как владелец уже взрослый Михаил Михайлович. «Женихъ сельца Чермошной Господина подпорудчика Михаила Михайлова Достоевскаго крепосной крестьянинъ Ларіонъ Васильевъ <...>, нивтьста сельца Дороваго господина Достаевскаго крепосная крестьянская дочь Лизовета Савинова...». Поручителем от лица новобрачных и поезжан выступает все тот же дворовый человек сельца Дарового Григорий Васильев.

Тот же владелец значится и в записи от 26 апреля следующего 1842 г.: «... женихъ сельца Черемошны Господина Подпоручика Михаила Михайловича Достаевскаго крппостной крестьянской сынъ Василій Михайловъ <...> невпста съ тогожь упзда сельца Дороваго означеннаго Господина Достаевскаго крпопотная крестьянская дочь Наталья Спмеонова...». Вначале свидетельствует уже знакомый служитель господина Павла Петровича Хотяинцева Алексей Сергеев из села Моногарова. Далее следует по-своему интересная запись малоразборчивым почерком: «Кг сему обыску вмтьсто воченнаго Старосты сельиа Дороваго Г<оспод> Достоевскихь крисянина $<$ так!> Савина Макарова, импющаго доверие оть Госпоть своихъ о позволюніи въ ступить въ законный бракъ выше писанаго сельца Чермошны кресьянскаго сына Василья Михайлова...» по просьбе венчающихся и поезжан «изключеный ученикъ села Моногарова дячка Степана Васильева сынъ Петръ Покровский руку приложилъ» ${ }^{17}$. В данной записи интересно и упоминание старосты села Дарового Савина Макарова, которое более в наших обыскных книгах не встречается.

Запись следующего брачного обыска, состоявшегося пять месяцев спустя, -2 октября 1842 г. (за № 16) ${ }^{18}$, — в отличие от апрельской, возвращает нас к прежней формулировке «покойного господина коллежского советника (без кавалера. - Е. В.) Михаила Андреева Достоевского»: «...женихъ сельца Доровой покойнаго Господина Коллежскаго совптника Михаила Андрпева Достаевскаго крепостной крестьянской сынъ Иванъ Сидоровъ <...>. Невтьста тогожъ господина сельца Чермошной...». Подписывается от лица свидетелей по личному прошению их снова Петр Покровский: «...села Моногарова вмтьстнаго дьячка Стефана Васильева сынғ Венёвскаго уезнаго училищза исключеньной учиникъ».

Далее указания на владельца крестьян Дарового и Чермошны сводятся к формулировке: «покойный господин Михаил Андреевич Достоевский»уже без указания званий, вплоть до 2 мая 1847 г. (л. 50 об.), когда формулировка 
сокращается: «Господина Достоевского». В записи от 3 ноября 1846 г. (л. 52) появляется множественное число: «Г<оспод> Достоевских». В последующих записях указания на владельцев беспорядочно чередуются: множественное число «Господ Достоевских» - 29 октября (л. 62 об.) и 14 ноября 1848 г. (л. 63), безликое «Господина Достоевского» - 10 апреля 1849 г. (л. 64), «покойного Господина Достоевского» - 12 мая (л. 55 об.) и 20 июля 1847 г. (л. 58), а также 17 октября 1848 г. (л. 61 об.); «покойного Надворного советника» - далее, видимо, было оставлено место, куда позднее попытались вписать имя: «Михаила Андревича Досто» (фамилия полностью не поместилась и отчество написано с ошибкой) - запись от 22 января 1850 г. (л. 76).

Интересная запись появляется 3 июля 1850 г. за № 11 (л. 84 об. - 85). Она посвящена свадьбе жениха «деревни Черемошны Г-на Достаевскаго» крепостного и невесты «сельца Даровой тогожь Г-на Достаевскаго». Далее размещена запись поручителя: «Къ сему обыску вмпсто жениха и невпсты и вмпсто поручителей по женихп: деревни Черемошны крестьянб: Алекспя Михайлова и Василія Максимова; по невпсте сельиа Дароваго вмпсто крестьянъ Бориса Иванова и Ивана Сидорова за неумпніемъ ихъ грамматы Подпоручикъ Достоевскій руку приложилъ». Это последний автограф члена семьи Достоевских ${ }^{19}$.

Еще трижды в обыскных записях сельцо Даровое и деревня Черемошня упоминаются как владения господина или господ Достоевских: 11 сентября 1850 г., 4 ноября 1851 и 13 августа 1852 гг.

- 11 сентября 1850 г. (л. 85): «женихъ деревни Черемошны Г-на Достаевскаго», «невиста тогожъ сельца Господина». Поручительство Александра Степанова.

- 4 ноября 1851 г. (л. 92): «женихъ Сельияа Доровой Г. Достаевскихъ <...> невтьста тогожъ сельиа и Господъ». Поручитель - священник Григорий Михеев.

- 13 августа 1852 г. (л. 96 об.): «женихъ сельиа Черемошны Г-на Достаевскаго крепостный крестьянскій сынъ Иванъ Алекспевъ <...> невпьста сельиа Доровой тогожь Господина крепостная крестьянская дочь Лукерья Феодорова». Это последняя запись, в которой упоминается фамилия Достоевских.

С 18 января 1853 г. фамилия семьи писателя исчезла из обыскных книг. С этого времени сельцо Даровое (л. 99 об.) и сельцо Черемошна (л. 100) стали принадлежать госпоже Вере Михайловне Ивановой, замужней младшей сестре Ф. М. Достоевского. Сначала она просто именуется как «госпожа Иванова». С 24 июня 1855 г. она значится уже как «госпожа Коллежская Совптница Вира Михайлова Иванова» ${ }^{20}$.

Записи от 24 июля 1855 г. - последние в книге о владельцах Дарового и Черемошны за 1838-1855 гг. Следует добавить, что Вера Михайловна 
Иванова (урожденная Достоевская, 1829-1896) жила в Даровом до самой своей смерти [Нечаева, 1939: 61].

Установленные нами факты из жизни семьи Достоевских в Даровом открывают новые перспективы в дальнейших исследованиях биографии писателя.

\section{ПРИМЕЧАНИЯ}

* Исследование выполнено при финансовой поддержке Российского фонда фундаментальных исследований (РФФИ), проект № 18-012-90018 («Неизвестные и малоизвестные источники биографии Ф. М. Достоевского в собрании Государственного музея истории российской литературы им. В. И. Даля»).

Ф. 81. Оп. 1. Ед. хр. 128.

2 Даль В. И. Толковый словарь живого великорусского языка: в 4 т. СПб.; М.: Издание М. О. Вольфа, 1881. Т. 2: И-О. С. 659.

3 Брокгауз Ф. А., Ефрон И. А. Энциклопедический словарь. Том ХХІа. СПб., 1897. С. 643.

4 Лист с этой записью воспроизведен на с. 113 и дана запись до этого места на с. 155 в вышеуказанной книге публикации В. С. Нечаевой [Нечаева, 1939].

Ф. 81. Оп. 1. Ед. хр. 128. Л. 136.

6 Подробнее об этом пожаре и Г. Васильеве вспоминал А. М. Достоевский [Достоевский А. М.: 61-62].

7 Ф. 81. Оп. 1. Ед. хр. 130.

8 Подпись второго поручителя отсутствует.

9 Чермошня именуется то как сельцо, то как деревня. Само написание варьируется.

10 Ф. 81. Оп. 1. Ед. хр. 130. Л. 10.

11 Ф. 81. Оп. 1. Ед. хр. 131.

12 Видимо, малое число листов (всего 34) в предыдущей обыскной книге 1832-1838 гг. связано с реформами.

13 Ф. 81. Оп. 1. Ед. хр. 131. Л. 1.

14 Ф. 81. Оп. 1. Ед. хр. 131. Л. 6 об.-7.

15 Ф. 81. Оп. 1. Ед. хр. 131. Л. 14 об., 17 об., 18 об.

16 Ф. 81. Оп. 1. Ед. хр. 131. Л. 19 об.

17 Ф. 81. Оп. 1. Ед. хр. 131. Л. 21.

18 Ф. 81. Оп. 1. Ед. хр. 131. Л. 28 об.

19 Далее расположены подписи священника, дьякона, дьячка и пономаря церкви села Моногарова.

20 Ф. 81. Оп. 1. Ед. хр. 131. Две записи от 24 июня 1855 г. Л. 114 об., 115.

\section{СПИСОК ЛИТЕРАТУРЫ}

1. Достоевский А. М. Воспоминания. - М.: Аграф, 1999. - 432 с.

2. Достоевский Ф. М. Полн. собр. соч.: в 30 т. - Л.: Наука, 1981. - Т. 22. - 407 с.

3. Нечаева В. С. В семье и усадьбе Достоевских: письма М. А и М. Ф. Достоевских. - М.: Государственное социально-экономическое издательство, 1939. - 158 с.

4. Нечаева В. С. Из воспоминаний об истории основания первого музея Ф. М. Достоевского // Достоевский. Материалы и исследования. - Л.: Наука, 1985. - Т. 6. - С. $274-$ 295. 
Evgenya M. Varentsova

The Russian Literary History State Museum Named After V. I. Dahl

(Moscow, Russian Federation)

orfglm@gmail.com

\title{
Dostoevsky in Darovoe. Based on the Materials of the Manuscript Department of the Russian Literary History State Museum Named After V. I. Dahl
}

\begin{abstract}
Acknowledgement. The reported study was funded by RFBR according to the research project no. 18-012-90018 Dostoevsky.

Abstract. There is very little documentary evidence of Fedor Dostoevsky's childhood and adolescence. Besides the "direct" evidence, there are also the so-called "indirect" ones, in which the pages of Dostoevsky's biography or events related to the life of the writer's family are recorded indirectly. Such sources, first of all, are all sorts of official papers related to the property and economic sphere. In the the Manuscript Department of the Russian Literary History State Museum Named After V. I. Dahl there are "search books" of the Church of the Descent of the Holy Spiriton the Apostles in the village of Monogarovo, the analysis of which allowed us to make additional touches to the story of the daily life of Dostoevsky's family, add some new dates into the "Chronicle of life and work of F. M. Dostoevsky". The article gives an archaeographic description of the documents. A special attention is paid to the autographs of Maria Fedorovna, Mikhail Andreevich and Mikhail Mikhailovich Dostoevsky dated back to the 1830s-1850s.

Keywords: Fedor Dostoevsky's childhood, Mariya Fedorovna Dostoevskaya, Mikhail Andreevich Dostoevsky, Mikhail Mikhailovich Dostoevsky, Vera Mikhailovna Ivanova, search books, Darovoe, Monogarovo
\end{abstract}

About the author: Varentsova Evgeniya M. - Head of Department of the manuscript holdings, the Russian Literary History State Museum Named After V. I. Dahl (State Literary Museum) (ul. Dostoevskogo 2, Moscow, 103030, Russian Federation)

Received: July 25, 2019

Date of publication: September 14, 2019

For citation: Varentsova E. M. Dostoevsky in the Darovoe. Based on the Materials of the Manuscript Department of The Russian Literary History State Museum Named After V. I. Dahl. In: Neizvestnyy Dostoevskiy [The Unknown Dostoevsky], 2019, no. 3, pp. 5-17. DOI: 10.15393/j10. art.2019.4121 (In Russ.)

\section{REFERENCES}

1. Dostoevskiy A. M. Vospominaniya [Memories]. Moscow, Agraf Publ., 1999. 432 p. (In Russ.)

2. Dostoevskiy F. M. Polnoe sobranie sochineniy: $v 30$ tomakh [Complete Works: in 30 Vols]. Leningrad, Nauka Publ., 1981, vol. 22. 407 p. (In Russ.)

3. Nechaeva V. S. V sem'e i usad'be Dostoevskikh: pis'ma M. A. i M. F. Dostoevskikh [In the Dostoevskys Family and Estate: Letters of Mikhail A. and Maria F. Dostoevsky]. Moscow, Gosudarstvennoe social'no-ekonomicheskoe izdatel'stvo Publ., 1939. 158 p. (In Russ.)

4. Nechaeva V. S. From the Memories of the History of the Foundation of the First Museum of F. M. Dostoevsky. In: Dostoevskiy. Materialy i issledovaniya [Dostoevsky. Materials and Researches]. Leningrad, Nauka Publ., 1985, vol. 6, pp. 274-295. (In Russ.) 